\title{
Home range and habitat use of Reeves's Pheasant Syrmaticus reevesii in the protected areas created from forest farms in the Dabie Mountains, central China
}

\author{
JI-LIANG XU, ZHENG-WANG ZHANG, GUANG-MEI ZHENG, XIAO-HUI \\ ZHANG, QUAN-HUI SUN and PHILIP McGOWAN
}

\begin{abstract}
Summary
Many recently designated or expanded nature reserves in China were forest farms that ceased operations in the aftermath of the catastrophic Yangtze River floods of 1998. Although the vegetation in many of these areas has been altered significantly during forestry operations, there is now an opportunity to reduce, or even reverse, habitat loss for wildlife species that inhabit these forests. One such species is the globally threatened Reeves's Pheasant Syrmaticus reevesii that is endemic to the forested mountains of central and south-west China. From April 2000 to August 2003, the habitat use by 14 male Reeves's Pheasants was studied by radio-tracking at Dongzhai National Nature Reserve in the Dabie Mountains, central China. Conifer-broadleaf mixed forest was used preferentially in all seasons at the study area scale, as were mature fir plantations and shrubby vegetation. Moreover, young fir plantations were used preferentially during the breeding season at the scale of the home range. Surveys recorded the pheasant in 13 other protected areas in the Dabie Mountains, and indicated that broadly similar habitat types were available in all of them. Furthermore, Reeves's Pheasant were found in habitats similar to those used preferentially at Dongzhai National Nature Reserve. It seems likely that a mosaic of habitats is crucial to meet the various requirements of male Reeves's Pheasants throughout the year and management should therefore concentrate on maintaining this mosaic. It is now important to identify the habitats that produce the most young pheasants so that nesting and brood-rearing habitats can be clearly identified. Further studies on the habitat mosaic would be useful, both at a local scale and also at a larger, landscape scale.
\end{abstract}

\section{Introduction}

The Chinese government has taken a series of actions to conserve forests in recent years. This includes a ban on logging in the middle and upper reaches of large rivers that was imposed under the National Forest Protection Programme after the Yangtze River floods in 1998 (Liao 1999, BirdLife International 2003). Whilst this logging moratorium was designed to protect the water management function of forests in major river drainages, it also contributed significantly to biodiversity conservation (Hao et al. 2000). As a result, forest farms that operated in these areas are no longer charged with timber production and have been designated as protected areas, particularly nature reserves. Among the 1,228 new nature reserves established throughout the country during 1998-2006, 161 are national nature reserves and 303 are provincial reserves, and more than $85 \%$ of the new protected areas were created from forest farms (data from the State Forestry Administration database). Now the challenge is to guide management at these former 
forest farms so that the habitats present can benefit key elements of native biodiversity. Within China, pheasants and other species in the order Galliformes are both of global biodiversity conservation significance and seem likely to benefit significantly from enhanced forest management (Zhang et al. 2003).

Twenty-four per cent of the world's 50 species of pheasant are threatened with extinction (IUCN 2004), making them one of the most threatened groups of birds. China is especially important for the conservation of the world's galliforms, as 55 species have been recorded (Zheng 2005), and 15 of these are considered to be globally threatened (Madge and McGowan 2002, IUCN 2004). Although hunting is perceived to be a significant pressure on pheasants in some areas (Fuller and Garson 2000, McGowan 2002), it is clear that habitat loss and fragmentation are the main threats to their survival (Zhang et al. 2003). The establishment and good management of protected areas will provide an opportunity to reduce or even reverse the habitat degradation suffered by many pheasants.

One such species that may benefit from this change in land management is Reeves's Pheasant Syrmaticus reevesii, a threatened species that is endemic to China (Cheng 1987). It naturally inhabits broadleaf habitats dominated by oaks Quercus spp. in subtropical forests with a dense canopy and sparse undergrowth, at altitudes of 200-2,600 m (Xu et al. 1991, Wu et al. 1994). The species was widespread and common in central China historically (Cheng et al. 1978), but some populations have been extirpated because of illegal hunting, habitat loss and fragmentation (Xu et al. 1991, 1995, MacKinnon et al. 1996, Zheng and Wang 1998), and the geographical distribution of Reeves's Pheasant in China has been split into two major blocks (Zheng and Wang 1998). Consequently, it is listed on the IUCN Red List as Vulnerable (IUCN 2004), and as a national second-grade protected wildlife species (State Council 1988). Recently, threatened pheasants have been considered to be an important target species-group in the National Wildlife Rescue Program of China, which was officially launched in December 2001 (State Forestry Administration 2001, Zhang et al. 2003). Several studies of Reeves's Pheasant have been undertaken in the last decade, including general habitat status (Wu et al. 1994), wintering habitat (Fang and Ding 1997, Sun et al. 2001, Xu et al. 2005, 2006), roost-site (Sun et al. 2002), brood habitat (Xu et al. 2002), territory (Sun et al. 2003), incubation behaviour (Zhang et al. 2004) and molecular phylogeny (Zhan and Zhang 2005). However, there is little quantitative information on its habitat requirements, movements and seasonal variation in a managed landscape. Whilst gathering such data on an elusive species is not easy, it is clear that we must adopt an adaptive management approach so that the plantations and other forestry areas can be better managed for conservation in the new protected areas.

We therefore sought to provide information on habitat use of the globally threatened Reeves's Pheasant in nature reserves created from forest farms. Specifically, the objectives were to: (I) assess the home range, the habitat use pattern and its seasonal variation of Reeves's Pheasant in such managed areas; and (2) discuss the management of habitats for Reeves's Pheasant in these protected areas.

\section{Methods}

\section{Study site selection and study area}

We selected study sites in the Dabie Mountains, as they comprise the major portion of the eastern distribution of Reeves's Pheasant in China (Zheng and Wang 1998). Dongzhai National Nature Reserve $\left(31^{\circ} 4 \mathrm{O}^{\prime} \mathrm{N}, 114^{\circ} 24^{\prime} \mathrm{E}\right)$, a former forest farm that is located on the northern slopes of the Dabie Mountain range in Henan province of central China, was selected as our intensive study area. Dongzhai National Nature Reserve was highlighted as one of the 12 most significant Important Bird Areas in the South-east China forest region (BirdLife International 2003) because of its population of Reeves's Pheasant. Fieldwork was carried out from April 2000 to August 2003. An area of $100 \mathrm{~km}^{2}$ was designated as Dongzhai provincial nature reserve in 1982 
(Song and Qu 1996). This was expanded to $450 \mathrm{~km}^{2}$ and upgraded to a national nature reserve in 2001. Much of the additional area was agricultural farmland, shrubby areas and built on, occupying areas of $83 \mathrm{~km}^{2}, 170 \mathrm{~km}^{2}$ and $57 \mathrm{~km}^{2}$, respectively. The reserve is located in the northern subtropical zone where the natural vegetation is characterized by mature forests dominated by oaks Quercus spp., Masson Pine Pinus massoniana, Dyetree Platycarya strobilacea, Beautiful Sweetgum Liquidambar formosana and Hupeh Rosewood Dalbergia hupeana. Mature coniferous plantations dominated by Chinese Fir Cunninghamia lanceolata occur in the study area. There are also some tea Camellia spp. gardens and young plantations of Chinese Fir. Shrubby areas are dominated by young oaks, young Chinese Firs and Glaucous Allspice Lindera glauca.

Previous studies have reported that Reeves's Pheasant in this reserve concentrated in the original area, especially in the core areas of this reserve (Song and Qu 1996, Xu et al. 2006). Therefore, a 400 ha part of the core area at Baiyun was selected as the main study area (Figure 1 ). The altitude of this site ranges from $100 \mathrm{~m}$ to $446 \mathrm{~m}$, and the climate is warm and humid, with mean annual temperature of $15.1{ }^{\circ} \mathrm{C}$ (range $18.2-40.1{ }^{\circ} \mathrm{C}$ ) and mean annual precipitation of $1,209 \mathrm{~mm}$.

\section{Capture and radio-tracking}

Male Reeves's Pheasants were caught using a live decoy during territory establishment during April-May. Nets were placed around the decoy and males were caught as they approached the decoy (Sun et al. 2003). This method only works when the males are territorial during the breeding season. Each bird was fitted with a coloured plastic leg ring and a necklace radio transmitter (Biotrack, U.K.), with frequencies between 216.00 and 217.00 MHz. Each transmitter weighed $16 \mathrm{~g}$, less than $2 \%$ of the male body weight.

The tagged pheasants were located using a portable TR-4 receiver and a Telonics hand-held antenna. Radiolocations were collected by triangulation from permanent reference points between 05 hoo and $19 h_{30}$ or by direct observations. In most instances $(>95 \%)$ the distance from observer to pheasant was less than $200 \mathrm{~m}$. All azimuths were collected within a 3 minute period and triangulation angles were between $45^{\circ}$ and $135^{\circ}$ to reduce telemetry error (Kenward 2001). The time between consecutive radiolocations averaged 12 hours.

Locations were partitioned into four seasons: spring (March-May), which encompassed most mating activity; summer (June-August), when females were rearing broods; autumn (September-November), when young were still associated with their female parent; and winter (December-February), when birds gathered into flocks.

\section{Habitat measurement and analysis}

Habitat use was analysed using home range and individual locations. Home ranges were calculated by $95 \%$ fixed kernel estimators, which were obtained using a fixed kernel method with least squares cross-validation for the smoothing factor (Worton 1989) available in Animal Movement (Hooge and Eichenlaub 1997), an extension to ArcView GIS 3.2 (Environmental Systems Research Institute 1999). The seasonal home ranges and core areas were estimated for individuals with 30 or more locations in a season, while the annual home ranges and core areas were estimated for ones with 30 or more locations in a year. This number of locations is adequate for fixed kernel home ranges (Seaman et al. 1999).

To measure the extent of habitat blocks in the study area, a 1:10,00o vegetation map supplied by the management bureau of the nature reserve was ground-truthed by point observations located $200 \mathrm{~m}$ apart throughout the study area. Each point was checked once each season and the plant composition was recorded. This map was digitized to produce a land-cover map of the study site using ArcView GIS 3.2 (Environmental Systems Research Institute 1999). The habitats 

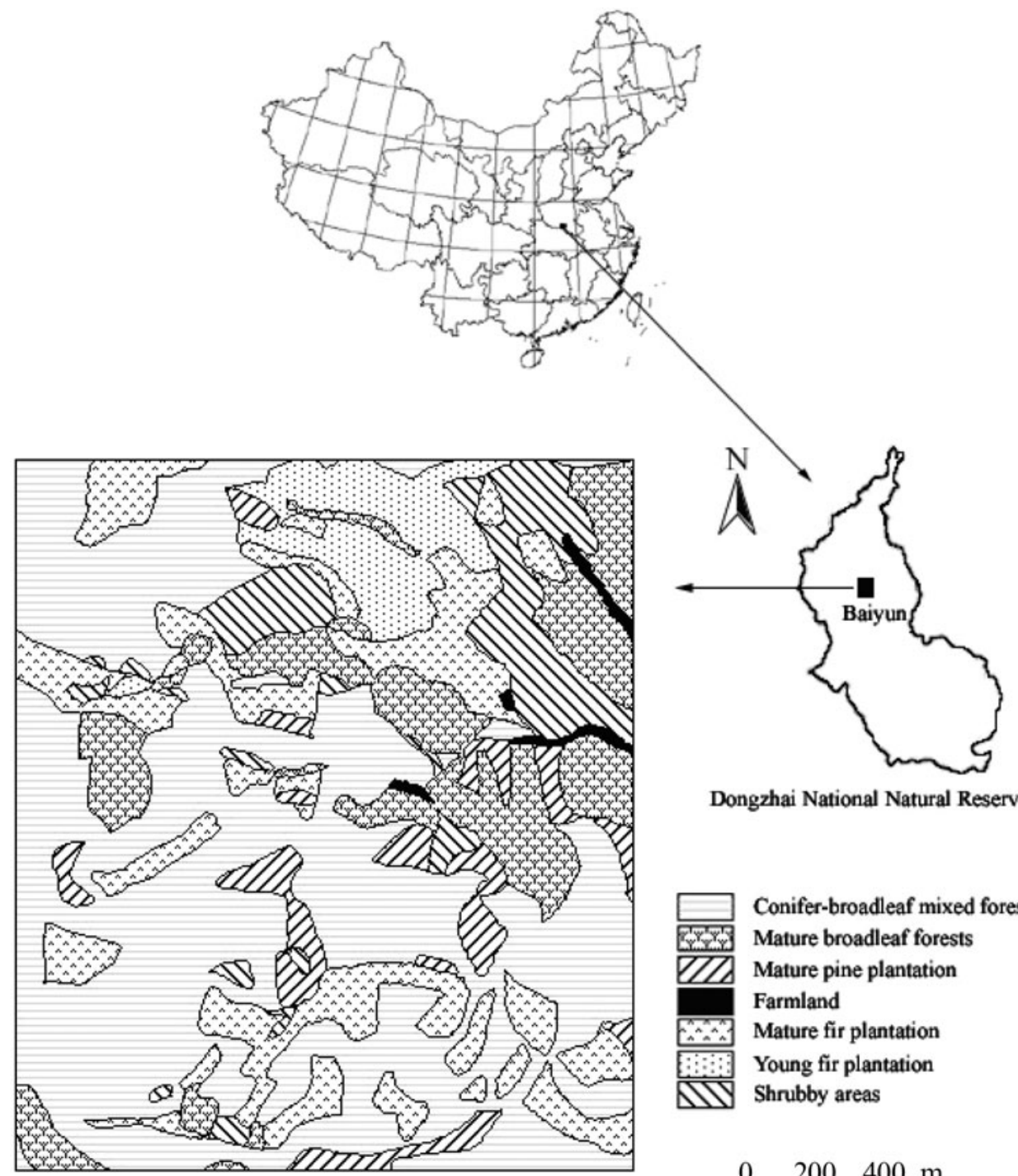

Dongzhai National Natural Reserve

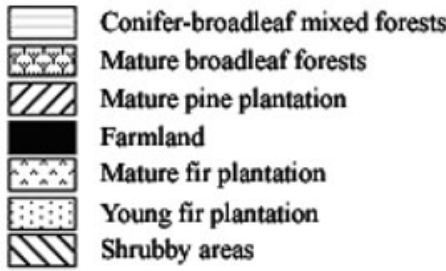

Figure 1. Study site and its habitats in Dongzhai National Nature Reserve, Henan province, central China.

within this site were classified according to plant species present (dominant tree species, such as oak, fir or pine), their composition, and the proportions of the area that they occupied. Overall availability of habitats was quantified by (I) area occupied by a habitat relative to the total area and (2) number of fixed locations present within a habitat relative to the total number of locations for a pheasant.

Habitat use in four seasons by Reeves's Pheasant was evaluated using compositional analysis (Aebischer et al. 1993). This method is very informative in analysing location data and it accounts for the extent of each habitat that is actually available (habitat availability was considered as the denominator in the calculation of the log ratios: Aebischer et al. 1993). Using 
this method, we compared the proportion of each habitat used by an individual with the proportion of that habitat which was available to it at two spatial scales. At a broader scale, we treated habitats within the total available area in the study site as available and those within the home range as used. At a finer scale, we treated habitat within the home range as available and the proportion of the radio-locations within each habitat type as used. Each individual was treated as one sample.

MANOVA was used to determine a Wilk's $\Lambda$ value to evaluate whether differences in logtransformed use and availability proportions differed significantly from zero. Randomization tests were used when the sample size in a season was small (Edgington 1995, Conner et al. 2003). In the event of significant non-random habitat use, all possible habitat type pairs were compared by $t$-tests, and the habitat types were then ranked in order of use.

Means are given as mean $\pm I$ standard deviation (SD). Randomization was executed by psychStats (http://www.lcsdg.com/psychStats) online. Other statistical procedures were carried out using the software SPSS 10.0.I for Windows (SPSS 1999).

\section{Habitat use by Reeves's Pheasants in other protected areas in the Dabie Mountains}

Other protected areas in the Dabie Mountains of central China where Reeves's Pheasant occurred were identified from information obtained by field surveys in 2001 and 2002 (Zhang 2002), interviews with local people, or correspondence with professionals who were familiar with protected areas and with Reeves's Pheasant. Some were surveyed in one season and some in two seasons. We showed pictures of Reeves's Pheasants to the local people, especially the managers of these protected areas, and if they reported that the species occurred, we conducted fieldwork to determine the habitat that the pheasant used. Line transects were distributed randomly in these areas, and all these line transects were surveyed repeatedly in winter or spring. The surveys were conducted from o6hoo to 10 hoo and 16 hoo to 19 hoo in all habitats present at each site.

\section{Results}

\section{Habitats in the core area of Dongzhai National Nature Reserve}

Seven habitat types were identified in the core area of Dongzhai National Nature Reserve (Figure 1 ), as follows:

(I) Conifer-broadleaf mixed forests, dominated by oak, Masson Pine and Chinese Fir comprise $50.0 \%$ of the study site. The broadleaf trees occur naturally, but the conifers have been planted. Canopy cover is high in all seasons in this habitat.

(2) Naturally occurring broadleaf forest, much of which is secondary and was logged 20 years ago. There are also areas where broadleaved trees have been planted, possibly also 20 years ago. Together these account for $14.0 \%$ of the study site. The plantation part of the broadleaf forest is dominated by oaks Quercus spp. that were planted for various uses, most notably the production of acorns which are an important economic crop. This habitat has a dense canopy in spring and summer, but becomes sparse in autumn, and especially in winter. Some parts of this habitat were subject to significant human activity.

(3) Mature pine plantation dominated by Masson Pine trees that are at least 20 years old account for $6.0 \%$ of the study site; it has a sparse undergrowth and a dense canopy throughout the year.

(4) Mature Chinese Fir plantation dominated by trees that are at least 20 years old accounts for $16.1 \%$ of the study site; it also has a sparse undergrowth and a dense canopy throughout the year.

(5) Young Chinese Fir plantation that is less than 5 years old and with trees $<2$ m tall occupies $5.6 \%$ of the study site. 
(6) Shrubby vegetation $<_{3} \mathrm{~m}$ in height and which is the result of natural regeneration within the last 5 years accounts for $7.8 \%$ of the study area. These areas contain Lindera glauca, Rosa cuimosa, Lespedezea spp. and Vitex negundo.

(7) Farmland occupies only $0.6 \%$ of the study site, is mostly situated at the edge of the site and is subject to severe human impact throughout the year.

\section{Habitat use and seasonal variation}

Seventeen male Reeves's Pheasants were captured and radio-tagged between 2000 and 2002 (9, 5 and 3 individuals in April 2000, 2001 and 2002, respectively). Altogether 1,694 radio-locations were recorded. The sample sizes in spring, summer, autumn, winter were 12, 10, 6 and 5 individuals, respectively. The home range of males ranged from 9.5 to 23.9 ha.

At the broader scale of home range establishment within the study site, male Reeves's Pheasant were selecting particular habitats throughout the year (Table 1). Mixed forests were used more than they were available $\left(t_{11}=4.455, P<0.001\right)$ in spring; pine forests were used less than available $\left(t_{9}=-2.964, P=0.016\right)$ in summer; and young plantation was used less than available in autumn and winter (autumn: $t_{5}=-2.908, P=0.033$; winter: $t_{4}=-2.918, P=$ 0.043). In addition, farmland was used less than available $(P<0.05)$ in all seasons. In general the pattern of habitat use was similar throughout the year (Table 1 ), especially in spring and summer. Mixed forest, mature fir plantation and shrubby areas were used significantly more than young plantation and farmland in all four seasons $(P<0.05)$. In spring and summer, mixed forest and mature fir plantation were used more than other habitat types $(P<0.05)$ except for broadleaf forest.

At the finer scale of habitat use within the home range, male Reeves's Pheasants used habitats non-randomly in spring and summer when comparing habitats used and those available in the home range (Table 1$)$. Mixed forests were used more than available in summer $\left(t_{9}=-2.323, P\right.$ $=0.045)$, as was young plantation $\left(t_{9}=3.662, P<0.005\right)$, whereas shrubby areas were used less than available in spring and summer (spring: $t_{11}=2.061, P=0.044$; summer: $t_{9}=-3.032, P=$ o.014). Overall, mixed forest and young plantation were used more than other habitats $(P<$ $0.05)$ and young plantations were used more than mixed forest, mature fir plantation and shrubby vegetation $(P<0.05)$.

Table 1 . Seasonal habitat rankings from compositional analysis of habitat use by male Reeves's Pheasant in central China.

\begin{tabular}{|c|c|c|c|c|c|c|}
\hline \multirow{3}{*}{$\begin{array}{l}\text { Order } \\
\text { Home } \\
\text { range vs } \\
\text { study area }\end{array}$} & \multirow{2}{*}{$\begin{array}{l}\text { Season } \\
\text { Spring }\end{array}$} & \multirow{2}{*}{$\begin{array}{l}\text { Males } \\
12\end{array}$} & \multicolumn{2}{|c|}{ Wilk's $\Lambda \mathrm{df}$} & \multirow{2}{*}{$\frac{F}{71^{* *}}$} & \multirow{2}{*}{$\begin{array}{l}\text { Ranking of habitats }^{\mathrm{a}} \\
\text { Mixed }=\text { Fir }>\text { Shrub }>\text { Broadleaf }>\text { Pine }> \\
\text { Young plantation }>\text { Farmland }\end{array}$} \\
\hline & & & 0.038 & 6,17 & & \\
\hline & Summer & 10 & 0.003 & 6,13 & $715^{* *}$ & $\begin{array}{l}\text { Mixed }=\text { Fir }>\text { Shrub }>\text { Broadleaf }>\text { Pine }> \\
\text { Young plantation }>\text { Farmland }\end{array}$ \\
\hline & Autumn & 6 & 0.001 & 5,6 & $2150^{*}$ & $\begin{array}{l}\text { Fir }>\text { Mixed }>\text { Shrub }>\text { Broadleaf }>\text { Pine }> \\
\text { Farmland }>\text { Young plantation }\end{array}$ \\
\hline & Winter & 5 & 0.013 & 4,5 & $94^{*}$ & $\begin{array}{l}\text { Shrub }>\text { Mixed }>\text { Fir }>\text { Broadleaf }>\text { Pine }> \\
\text { Farmland }>\text { Young plantation }\end{array}$ \\
\hline \multirow{4}{*}{$\begin{array}{l}\text { Fixed } \\
\text { locations } \\
\text { vs home } \\
\text { range }\end{array}$} & Spring & 12 & 0.210 & 5,14 & $11^{*}$ & $\begin{array}{l}\text { Mixed }>\text { Young plantation }>\text { Fir }>\text { Pine }> \\
\text { Broadleaf }>\text { Shrub }\end{array}$ \\
\hline & Summer & 10 & 0.201 & 6,13 & $9^{* *}$ & $\begin{array}{l}\text { Young plantation }>\text { Mixed }>\text { Fir }>\text { Broadleaf }> \\
\text { Pine }>\text { Shrub }\end{array}$ \\
\hline & Autumn & 6 & 0.044 & 5,6 & $26^{\mathrm{ns}}$ & - \\
\hline & Winter & 5 & 0.407 & 4,5 & $2^{\text {ns }}$ & - \\
\hline
\end{tabular}

${ }^{*} \mathrm{P}<0.05 ;{ }^{* * P}<0.01 ;$ ns, not significant.

${ }^{\text {a }}$ Ranks represent the importance of each habitat in descending order from most to least important. 
Habitat used by Reeves's Pheasants in other protected areas in the Dabie Mountains of central China

Reeves's Pheasant occurs in 13 other protected areas in the Dabie Mountains spanning three provinces: Anhui, Henan and Hubei (Table 2). The reserves were established for various reasons, with some reserves created specifically for the conservation of Reeves's Pheasant, such as Dongzhai National Nature Reserve while other reserves were established primarily for protecting the forest ecosystem. Eleven of the protected areas were forest farms before they became protected areas and, therefore, a considerable proportion of each has a history of logging and replanting.

The habitat types in these protected areas were similar to each other, comprising coniferbroadleaf forests, mature broadleaf forests, mature fir plantation, shrubby vegetation, pine plantation, young fir plantation and farmland. Only three protected areas held some secondary broadleaf forests, i.e. Tianma, Jigongshan and Liankangshan. However, the landscape mosaic of habitats in these protected areas was very different from each other. For example, the proportion of pine plantation in Zhonghuashan was $>80 \%$, but that in Lianhuashan was $<20 \%$.

Reeves's Pheasant in these protected areas used conifer-broadleaf mixed forest, mature fir plantation, shrubby vegetation or pine plantation in spring and winter (Table 2), but there were no Reeves's Pheasants recorded in broadleaf forest in winter, or in secondary broadleaf forests in two seasons (Zhang 2002).

\section{Discussion}

Assessments of habitat use of threatened species in former forest farms that are now protected areas in China are needed if management is to be designed to benefit them as much as possible. However, conducting such studies is often difficult because of low encounter rates, relatively low densities and difficult terrain over which to conduct fieldwork. The extent of the challenge is considerable given the number of threatened species, such as Reeves's Pheasant, that are likely to be present in China's new protected areas. Therefore, we advocate an adaptive management

Table 2. Protected areas that contain Reeves's Pheasant in the Dabie Mountains of central China.

\begin{tabular}{|c|c|c|c|c|c|}
\hline Name & $\begin{array}{l}\text { Level of } \\
\text { nature reserve }\end{array}$ & $\begin{array}{l}\text { Size } \\
\text { (ha) }\end{array}$ & Province & Habitats used & $\begin{array}{l}\text { Survey } \\
\text { methods }\end{array}$ \\
\hline Tianma $^{\mathrm{d}}$ & National & 28,914 & Anhui & Fir, mixed, pine, shrub & LT and ILP \\
\hline Yaoluoping & National & 12,300 & Anhui & Mixed, fir, pine & LT and ILP \\
\hline Bancang $^{c}$ & Provincial & 5,000 & Anhui & Fir, pine, shrub & $\mathrm{CP}$ \\
\hline Wanfoshan ${ }^{c}$ & Provincial & 1,523 & Anhui & Fir, shrub, pine & $\mathrm{CP}$ \\
\hline Kujingyuan $^{c}$ & Provincial & 2,000 & Anhui & Fir, pine, shrub & $\mathrm{CP}$ \\
\hline Jigongshan ${ }^{c, d}$ & National & 2,917 & Henan & $\begin{array}{l}\text { Fir, mixed, shrub, mature broadleaf, } \\
\text { pine }\end{array}$ & $\mathrm{CP}$ \\
\hline Dongzhai $^{c, d}$ & National & 46,800 & Henan & Mixed, fir, shrub, broadleaf, pine & LT \\
\hline Liankang Shan ${ }^{\mathrm{c}, \mathrm{d}}$ & National & 10,580 & Henan & Fir, pine, mixed, mature broadleaf, & LP \\
\hline Jingangtai $^{\mathrm{d}}$ & Provincial & 2,972 & Henan & Fir, pine, shrub & LP \\
\hline Taibaiding $^{\mathrm{c}}$ & Provincial & 4,924 & Henan & Fir, pine, shrub & $\mathrm{CP}$ \\
\hline Tianmushan $^{c}$ & Provincial & 6,750 & Henan & Fir, pine, shrub & $\mathrm{CP}$ \\
\hline Huangbaishan ${ }^{\mathrm{b}, \mathrm{d}}$ & Forest Park & 2,100 & Henan & Fir, shrub & LT \\
\hline Zhonghua Shan ${ }^{b, c, d}$ & Forest Park & 6,927 & Hubei & Fir, pine, shrub & LT \\
\hline Dabieshan $^{c}$ & Provincial & 44,011 & Hubei & Fir, pine, shrub & LT \\
\hline
\end{tabular}

${ }^{a}$ LT, line transects; ILP, interview with local people; CP, correspondence with professionals.

${ }^{b}$ Forest Park, i.e. an area where tourism is primary, and conservation is secondary.

${ }^{\mathrm{c}}$ The sites were investigated in winter.

${ }^{\mathrm{d}}$ The sites were surveyed in spring. 
approach (see Walters 1986, Salafsky et al. 2001, 2002) to enhance the value of these reserves for target species so that all current biological information is used in management whilst at the same time key knowledge gaps are filled with additional research. Therefore, we discuss the observed habitat use both within the reserve and elsewhere in the Dabie Mountains before drawing these management and research conclusions.

\section{Habitat use}

Male Reeves's Pheasants showed a significant preference for conifer-broadleaf forest, mature fir plantations and shrubby patches, compared with farmland and young fir plantations. The conifer-broadleaf forest seems likely to provide both good cover and food throughout the year (Sun 2001). The shrubby vegetation also probably provides good cover and many acorns, which in turn may provide plenty of food (Xu et al. 1991, Song and Qu 1996, Sun 2001, Xu 2004). Mature fir plantations were preferred significantly by the pheasants throughout the year and especially in autumn. Again, this is probably due to the provision of good cover and larger trees for roosting (Sun et al. 2001).

Although there was no significant preference for mature broadleaf forest, this forest type does offer some resources to the species. For example, it provides food and some nest-sites for females (Sun 2001) as well as roost-sites in spring and summer (Sun et al. 2002), as was the probably the case in this study. Many of the oak trees throughout a large proportion of the broadleaf forest produced acorns in sufficient quantity to make them one of the major agricultural products for people in this area. To make collection easier, they clear the undergrowth so that acorns can be seen on the ground more easily. Consequently, there was considerable human disturbance to Reeves's Pheasants in the autumn. In addition, the canopy of this habitat was sparse in spring and winter, which may lead to an increase in predation by raptors in this area (Xu et al. 2002).

It has been suggested that farmland might provide supplementary food for Reeves's Pheasants in some places, especially in winter (Xu et al. 1991, Wu et al. 1994). However, farmland was not an important habitat for the species in Dongzhai National Nature Reserve. Although some nontracked individuals were occasionally observed foraging in farmland near the forest edge in all four seasons, no radio-tagged individuals were observed in this habitat, which might imply that there was sufficient food within their home ranges, or that a lack of cover made them susceptible to predation.

Some individual birds that used young fir plantation within their home range showed a strong preference for this habitat. Sun (2001) stated that young plantations were the preferred nesting habitat of females, and so perhaps males used this habitat preferentially to increase the number of encounters with females.

\section{Other reserves with Reeves's Pheasant in the Dabie Mountains of central China}

A number of key locations for the species have now been turned into protected areas in this part of the range, but previous human exploitation may have led to some differences in the habitat mosaic between sites. Overall, forestry development and the expansion of agriculture have resulted in increased proportions of mature fir plantation and shrubby vegetation in these former forest farms.

Overall, the extent of natural broadleaf forest and conifer-broadleaf mixed forest has declined markedly as a result of logging activities (Xu et al. 1991, MacKinnon et al. 1996, Fuller and Garson 2000, BirdLife International 2001), and the proportion of mature fir plantation and shrubby vegetation has increased because of replanting after initial felling of natural forest stands. Indeed, mature fir plantations have become the most extensive habitat type in some protected areas, such as Jingangtai, Taibaiding and Liankangshan Nature Reserves. Field surveys revealed that mature fir plantations, shrubby vegetation and conifer-broadleaf mixed forest were 
used by Reeves's Pheasant in these reserves (Zhang 2002). Overall, the habitat types available and their use by Reeves's Pheasant in other protected areas appear broadly similar to that in Dongzhai National Nature Reserve. Therefore, it is possible that the conclusions drawn from this study at Dongzhai National Nature Reserve may be highly relevant to other protected areas.

\section{Adaptive management implications}

Although this study has not provided unequivocal information that can be used to produce a detailed habitat management prescription for Reeves's Pheasant in the reserves of the Dabie Mountains, it provides clear pointers that should be acted upon adaptively. Deciduous broadleaf forest containing conifer trees seems to have been the original habitat in the Dabie Mountains (Song and Qu 1996), but much forest was destroyed in the mid-1950s (BirdLife International 2003 ) and has been replaced with conifer-broadleaf mixed forest. Now, conifer-broadleaf mixed forest is the most extensive cover type in central China (Hou 2001). It was preferred significantly by male Reeves's Pheasant in Dongzhai National Nature Reserve and, therefore, maintaining this semi-natural habitat is likely to be critical for the survival of this species in the short to medium term. In recent decades, mature fir plantations have become a major part of the habitat mosaic in this landscape and male Reeves's Pheasants, at least, use this habitat. Shrubby vegetation was used preferentially by radio-tagged males, and the individuals in shrubby vegetation did not move far from forest (Xu et al. 2005) presumably because the bigger conifer trees were used for roosting (Sun et al. 2002). Thus, it is reasonable to assume that the proximity of forest and shrubby vegetation is a critical factor influencing habitat use by Reeves's Pheasants. Consequently, habitat management should aim to maintain the mosaic of habitats that exists, ensuring especially that there are sufficient patches of conifer-broadleaf mixed forest, young and mature fir plantation, and shrubby areas close to tall forest. If extensive areas of the original broadleaf forest become established in the future it will be important to evaluate how the species uses the habitats that are then present.

Young fir plantations were important for male Reeves's Pheasant in the breeding season and Sun (2001) states that females nest in this habitat. Therefore, maintaining suitable nesting habitat, which appears to be a relatively early successional stage in forest development, is crucial for the long-term conservation of this species. However, young plantations were subject to management in June and July each year when grass and other vegetation growing around saplings was removed, and this may interfere with the breeding activities of Reeves's Pheasant which may nest until June (Zhang et al. 2004). Therefore, it seems appropriate that routine annual management in young plantation should be carried out a little later so as to minimize negative impacts on the species' reproductive output.

There seem to be two key research areas arising from this study. The first is finding out which habitat types are most important for recruitment into the adult population, i.e. the best nesting and brood-rearing habitats. Although it can be inferred from this study that young fir plantations are used by nesting females, it is vital to confirm that successful nesting attempts are made in this habitat. Assumptions that the similarly threatened Swamp Francolin Francolinus gularis from India and Nepal bred successfully in sugar-cane plantations because many males were heard calling from that artificial habitat proved incorrect when radio-tracking revealed that the only successful nests were those in grassland or fallow farmland (Iqubal et al. 2003). The same study should also determine which brood-rearing habitats are crucial for the species and ensure that food availability is sufficient at this critical stage. The second research requirement is for a more thorough knowledge of the size and local proximity of habitat patches so that the species' needs can be met throughout the annual cycle. This should be contrasted with a larger scale landscape analysis of habitat use that includes assessing the dispersal of young birds and the connectedness of neighbouring populations. 


\section{Acknowledgements}

This work was supported by the National Sciences Foundation of China (No. 30330050, No. 30570234). The provincial government and the management bureau of Dongzhai National Nature Reserve granted permission for birds to be captured so that radio-transmitters could be attached. We thank Ruan Xiang-Feng, Zhang Ke-Yin, Zhu Jia-Gui, Gao Zhen-Jian and Liang Guo-Zhong for their assistance in the field. We are indebted to Xi Po and Du Zhi-Yong for their invaluable assistance during field work. We wish to acknowledge Prof. Zhang Yi-Li, Dr Liu LinShan and Zhang Wei in the GIS software application. We are grateful to Rufus Sage, Stephen Browne and two anonymous referees for their comments, which significantly improved the manuscript.

\section{References}

Aebischer, N. J., Robertson, P. A. and Kenward, R. E. (1993) Compositional analysis of habitat use from animal radiotracking data. Ecology 74: 1313-1325.

BirdLife International (2001) Threatened birds of Asia: the BirdLife International Red Data Book. Cambridge, U.K: BirdLife International.

BirdLife International (2003) Saving Asia's threatened birds: a guide for government and civil society. Cambridge, U.K: BirdLife International.

Cheng, T. H. (1987) A synopsis of the avifauna of China. Beijing: Science Press and Hamburg and Berlin: Paul Parey Scientific Publishers.

Cheng, T. H., Tan, Y. K., Lu, T. C., Tang, C. Z., Bao, G. X. and Li, F. L. (1978) Fauna Sinica, Aves. Volume 4: Galliformes. Beijing: Science Press.

Conner, L. M., Smith, M. D. and Burger, L. W. (2003) A comparison of distance-based and classification-based analysis of habitat use. Ecology 84: 526-531.

Environmental Systems Research Institute (1999) ArcView GIS 3.2 California: Redlands.

Edgington, E. S. (1995) Randomization tests. Third edition. New York: Marcel Dekker.

Fang, C. L. and Ding, Y. H. (1997) The winter ecology of Reeves's Pheasant (Syrmaticus reevesii). Chinese J. Ecol. 16: 67-68.

Fuller, R. A. and Garson, P. J. (200o) Pheasants: status survey and conservation action plan 2000-2004. Gland, Switzerland and Cambridge, U.K.: IUCN and Reading, U.K: World Pheasant Association.
Hao, Z. Q., Wang, Q. L. and Dai, L. M. T. (2000) The importance of the national programme for natural forests conservation on biodiversity conservation in northeast state owned forest areas of China. In Biodiversity Committee of the Chinese Academy of Sciences, ed. China's biodiversity conservation toward the 21st century: Proceedings of the Third National Symposium on the Conservation and Sustainable Use of Biological Diversity. Beijing: Chinese Forest Press.

Hooge, P. N. and Eichenlaub, B. (1997) Animal movement extension to ARCVIEW, v. 1.1. Anchorage: Alaska Biological Science Center, U.S. Geological Survey.

Hou, X. Y., ed. (2001) Vegetation of China. Beijing: Science Press.

Iqubal, P., McGowan, P. J. K., Carroll, J. P. and Rahmani, A. R. (2003) Home range size, habitat use and nesting success of the swamp francolin Francolinus gularis on agricultural land in northern India. Bird Conserv. Int. 13: 127-138.

IUCN (2004) 2004 IUCN Red List of threatened species. Available from: http:// www.iucnredlist.org (downloaded 12 November 2005).

Kenward, R. E. (2001) A manual for wildlife radio tagging. London: Academic Press.

Liao, Y. H. (1999) Rebuilt the Green Great Wall: report from the stop-logging areas in West Sichuan. Decision and Information 173: 4-5.

MacKinnon, J., Meng, S., Carey, C., Zhu, X. and Melville, D. (1996) A biodiversity 
review of China. Hong Kong: WWF International China Programme.

Madge, S. and McGowan, P. (2002) Pheasants, partridges $\&$ grouse. London: Christopher Helm.

McGowan, P. (2002) The conservation implications of the hunting of Galliformes and the collection of their eggs. Pp. 85-93 in S. A. Mainka and M. Trivedi, eds. Links between biodiversity conservation, livelihood and food security: the sustainable use of wild species for meat. Gland, Switzerland and Cambridge, U.K: IUCN.

Salafsky, N., Margoulis, R. and Redford, K. (2001) Adaptive management: a tool for conservation practitioners. Publication no.112. Washington, D.C.: Biodiversity Support Program. Available from: http:// www.bsponline.org (downloaded 20 October 2005).

Salafsky, N., Margoulis, R., Redford, K. H. and Robinson, J. G. (2002) Improving the practice of conservation: a conceptual framework and research agenda for conservation science. Conserv. Biol. 16: 1469-1479.

Seaman, D. E., Millspaugh, J. J., Kernohan, B. J., Brundige, G. C., Raedeke, K. J. and Gitzen, R. A. (1999) Effects of sample size on kernel home range estimates. J. Wildl. Manag. 63: 739-747.

Song, C. S. and Qu, W. Y. (1996) Scientific investigation on Dongzhai National Nature Reserve. Beijing: Chinese Forestry Press.

SPSS Inc. (1999) SPSS 10.0.1 for Windows: standard version. Chicago, IL: SPSS Inc.

State Council (1988) The List of Wild Animals Under National Protection. Issued by the State Council of the People's Republic of China on 10 December 1988. Beijing: State Council.

State Forestry Administration (2001) National wildlife conservation and nature reserve construction project. Document [2001]905 of the State Development Planning Commission. Beijing: State Development Planning Commission.

Sun, Q. H. (2001) The aggregating behaviour and habitat use of Reeves's Pheasant in Henan Province. Unpublished MSc Dissertation, Beijing Normal University, China.
Sun, Q. H., Zhang, Z. W., Ruan, X. F. and Zhang, K. Y. (2001) Studies on flocking behavior of Reeves's Pheasant in Dongzhai Nature Reserve, Henan province. J. Beijing Normal University (Nat. Sci.) 37: 111-116. Sun, Q. H., Zhang, Z. W., Zhu, J. G. and Gao, Z. J. (2002) Roosting behavior and factors affecting roost-site used by Reeves's Pheasant (Syrmaticus reevesii). J. Beijing Normal University (Nat. Sci.) 38: 108-112.

Sun, Q. H., Zhang, Z. W., Zheng, G. M., Zhang, K. Y., Ruan, X. F. and Zhu, J. G. (2003) Ranging behavior of territorial male Reeves's Pheasants in the breeding season. Acta Zool. Sinica 49: 318-324.

Walters, C. J. (1986) Adaptive management of natural resources. New York: Macmillan.

Worton, B. (1989) Kernel methods for estimating the utilization distribution in home-range studies. Ecology 70: 164-168.

Wu, Z. K., Li, Z. M. and Wang, J. H. (1994) Progress in research on Reeves's Pheasant in China. Annual Review of the World Pheasant Association 1993/1994: 39-43.

$\mathrm{Xu}$, J. L. (2004) Home range and habitat use of Reeves's Pheasant. Unpublished PhD Dissertation, Beijing Normal University, China.

$\mathrm{Xu}$, J. L., Zhang, X. H., Zhang, Z. W. and Zheng, G. M. (2002) Brood habitat characteristics of Reeves's Pheasant (Syrmaticus reevesii) in Dongzhai National Nature Reserve. Zool. Res. 23: 471-476.

Xu, J. L., Zhang, X. H., Zhang, Z. W., Zheng, G. M., Ruan, X. F. and Zhang, K. Y. (2005) Home range and habitat use of male Reeves's Pheasant (Syrmaticus reevesii) in winter in Dongzhai National Nature Reserve, Henan Province. Biodiv. Sci. 13: $416-423$.

Xu, J. L., Zhang X. H., Zhang, Z. W., Zheng, G. M., Ruan, X. F. and Xi, P. (2006) Multiscale analysis on wintering habitat selection of Reeves's Pheasant (Syrmaticus reevesii) in Dongzhai National Natural Reserve. Acta Ecol. 26: 2061-2067.

Xu, W. S., Wu, Z. K. and Li, Z. M. (1991) Reeves's Pheasant (Syrmaticus reevesii). Pp. 328-338 in T. C. Lu, R. S. Liu and F. Q. $\mathrm{He}$ eds. The rare and endangered gamebirds in China. Fuzhou: Fujian Science and Technology Press. 
Xu, Y. G., Yin, Z. H., Zhang, K. Y., Zhang, X. F. and Gao, Z. J. (1995) The status of Reeves's Pheasant at Dongzhai of Henan province and suggestion for conservation. Sinozoologia 12: 335-341.

Zhang, X. H., Xu, J. L., Zhang, Z. W., Xie, F. L., Zhang, K. Y. and Zhu, J. G. (2004) A study on the incubation behaviour of Reeves's Pheasant (Syrmaticus reevesii) by radiotelemetry. J. Beijing Normal University (Nat. Sci.) 40: 255-259.

Zhang, Z. W. (2002) Survey of the habitat fragmentation of Reeves's pheasant. Unpublished Small Grant Report to WWF-China. 16pp.
Zhang, Z. W., Ding, C. Q., Ding, P. and Zheng, G. M. (2003) The current status and a conservation strategy for species of Galliformes in China. Biodiv. Sci. 11: 414-421.

Zhan, X. J. and Zhang, Z. W. (2005) Molecular phylogeny of avian genus Syrmaticus based on the mitochondrial cytochrome $b$ gene and control region. Zool. Sci. 22: 427-435.

Zheng, G. M. (2005) A checklist on the classification and distribution of the birds of China. Beijing: Science Press.

Zheng, G. M. and Wang, Q. S., eds. (1998) China Red Data Book of endangered animals (Aves). Beijing: Science Press.

\section{JI-LIANG XU ${ }^{1}$, ZHENG-WANG ZHANG* , GUANG-MEI ZHENG, XIAO-HUI ZHANG,} QUAN-HUI SUN

Ministry of Education Key Laboratory for Biodiversity Sciences and Ecological Engineering, College of Life Sciences, Beijing Normal University, Beijing 100875, China.

\section{PHILIP MCGOWAN}

World Pheasant Association, 7-9 Shaftesbury Street, Fordingbridge, SP6 1JF, U.K.

*Author for correspondence; e-mail: zzw@bnu.edu.cn

${ }^{1}$ Present address: College of Nature Conservation, Beijing Forestry University, Beijing 100083, China.e-mail:xujiliang@bjfu.edu.cn

Received 15 July 2006; revision accepted 19 December 2006 